\title{
THE ONE-CHINA POLICY AND IMPLICATIONS OF U.S. INVARIABLE SUPPORT FOR TAIWAN
}

\section{Sheriff Ghali Ibrahim, Chubado Babbi Tijjani and Ahmet Arabaci}

Department of Political Science and International Relations, University of Abuja; Nile University of Nigeria

Email: sherfboy@yahoo.com; Phone: +234 7063372013

\section{Cite this article:}

Sheriff G.I., Chubado B.T., Ahmet A. (2021), The OneChina Policy and Implications of U.S. Invariable Support for Taiwan. African Journal of Law, Political Research and Administration 4(2), 40-52. DOI: 10.52589/AJLPRAXWXSCXJ8.

\section{Manuscript History}

Received: 29 June 2021

Accepted: 27 July 2021

Published: 17 Aug 2021

Copyright $\odot 2020$ The Author(s). This is an Open Access article distributed under the terms of Creative Commons AttributionNonCommercial-NoDerivatives 4.0 International (CC BY-NC-ND 4.0 ), which permits anyone to share, use, reproduce and redistribute in any medium, provided the original author and source are credited.
ABSTRACT: This paper discusses the concept of the one-China policy and how the United States support of Taiwan poses a challenge to stability in the region. The paper adopted the library descriptive instrument from historical research to come up with the available data in the paper. Findings show that, since 1949, the struggle between the Nationalist Republic of China and the Communist party escalated into a civil war which resulted in the defeat of Kuomintang and the establishment of the People's Republic of China (PRC), which took control of all mainland China. Only the island of Taiwan remained under the control of the ROC. Since then, both the ROC and the PRC have been claiming to represent all of "China", and both officially claim each other's territory. The paper concludes that China cannot forfeit the strait of Taiwan despite American support to the island. The deteriorating relationship between the U.S and China relationship has seen trade wars to accusations on the origins of the coronavirus to political buffering, to the sovereign of Taiwan and Hongkong, it just seems to be a manifestation of the SinoAmerican Cold War. The way things appear, the relationship between the U.S and China will further deteriorate largely because democracy and liberal order are being challenged by the political posture of China. The paper recommends that there is the need to maintain the non-interference principle by the two parties, the United States should know that Taiwan is China and therefore not meddle in the affairs of China and vice-versa.

KEYWORDS: China; Taiwan; Communist Party; United States, Policy; Kuomintang 


\section{INTRODUCTION}

In early December 2016, Tsai Ing-wen, Taiwan's President spoke with Donald Trump breaking decades of US diplomatic protocol. The United States government had in 1979 derecognised Taiwan or the Republic of China and recognised the Peoples Republic of China as the sole legal government of China in what is now known to be the One China Policy. The controversy dates back to 1949 when the victorious Communists established the People's Republic of China on the mainland, and the defeated Nationalists fled to Taiwan where they continued to claim sovereignty over all of China. (Slate, 2000). Before the defeat of the Nationalists, China was recognised as the Republic of China controlled by the Nationalists. The victory of the communist party saw President Nixon and Chairman Mao Tse-tung in 1972 agree to endorse the one-China policy in the Shanghai communiqué, issued jointly with the People's Republic. The communique stated that "all Chinese on either side of the Taiwan Strait maintain there is but one China and Taiwan is a part of China (Slate, 2000).

The seeming inconsistency present today exists because while the U.S. officially adheres to the one-China policy, it practices a de facto two-China policy. BBC reports that the US has approved arms sales to Taiwan worth around $\$ 1.8 \mathrm{bn}$. The Pentagon said the deal comprised three weapons systems, including rocket launchers, sensors and artillery. Taiwan's defence ministry said the weapons would help it "build credible combat capabilities and strengthen the development of asymmetric warfare" (BBC, 2020). The reality on the ground is that Beijing is wary of the relationship that exists between the U.S and Taiwan. However, what scares Beijing the most is the sale of weapons and military hardware by the U.S to Taiwan. Beijing strongly criticised the selling of weapons to Taiwan and warns the US "not to send any wrong signals to "Taiwan independence". China has also stepped-up military drills that it presents domestically as rehearsals for a future invasion of Taiwan, though experts say a conflict is not imminent (BBC, 2020).

Today's Taiwan however has seen some change. From inception, the people of Taiwan have considered the ROC government as the sole legitimate government over mainland China and Taiwan. This position however began to change in the early 1990s as democracy was introduced and new Taiwanese leaders were elected, changing to one that does not actively challenge the legitimacy of PRC rule over mainland China (Affairs, 2008). The objective of this paper, therefore, is to discuss the relationship between the United States of America and Taiwan. We will discuss the implications of the relationship between the US and Taiwan on The Peoples Republic of China.

\section{LITERATURE REVIEW}

Historically, Taiwan was first occupied by the Austronesian tribal people, who are thought to have come from what is now known as Southern China. It was a Dutch colony for a short while from 1624-1661, until the Qing dynasty which ruled Taiwan from 1683 to 1895 . This rule was cut short when the Qing government had to give Taiwan to the Japanese as an effect of losing the 1895 war. China was however reunified in 1928 but without the territories lost to Japan. Since this reunification, most of mainland China was governed by the Republic of China (ROC). The defeat of the Axis powers after the Second World War saw Japan relinquish "all right, title and claim to Formosa and the Pescadores (Taiwan) in the San Francisco Treaty of 
Peace of 1951 (Greeen, 2017). What is interesting, however, is that both the Republic of China and the People's Republic of China were parties to the treaty, and thus neither was declared a beneficiary of the Japanese renouncement.

In 1949, the ongoing struggle between the Nationalist Republic of China and the Communist party escalated into a civil war which saw China and the government (ROC) lose control of mainland China to the Communist Party, which established the People's Republic of China (PRC) and took control of all of mainland China. Only the island of Taiwan remained under the control of the ROC. Since then, both the ROC and the PRC have been claiming to represent all of "China", and both officially claim each other's territory. Until 1970 ROC was recognised as the government of China by all the other countries and the United Nations. ROC was one of the five permanent members of the Security Council. In 1971, via UN General Assembly Resolution 2758, China's representation was replaced by the PRC. This changed the world view and now when we say "China", we refer to the People's Republic of China (PRC). The Republic of China (ROC) is considered to be Taiwan. (Diffen, 2012).In the 1992 consensus, both governments agreed that there is only one "China" but each claimed to be the sole representative of the sovereignty of undivided China.

Today's Taiwan however has seen some change. From inception, the People of Taiwan have considered the ROC government as the sole legitimate government over mainland China and Taiwan. This position however began to change in the early 1990s as democracy was introduced and new Taiwanese leaders were elected, changing to one that does not actively challenge the legitimacy of PRC rule over mainland China (Affairs, 2008). Most Taiwanese citizens want to maintain the "status quo"; and are more likely to support "declaring independence" independence which must not attract a Chinese attack but does not unify Taiwan with China. The People's Republic of China on the other hand holds firm the notion that the Island of Taiwan is part of its territory. China regards Taiwan as a breakaway province which it has vowed to retake, by force if necessary. It has proposed the one country two system policy to accommodate the political system of Taiwan just as it did for the formal British colony Hong Kong. Taiwan has however rejected this offer and has continued on its part to independence through the help of western support, especially in their defence system. For China, the independence of Taiwan is simply an act of war. It is widely viewed by the Chinese on the mainland as the last vestige of the century of humiliation that began with the Opium Wars in the middle of the nineteenth century. The persisting separation of the mainland and Taiwan is also portrayed as a hindrance to China's re-emergence as a great power, which President Xi Jinping has dubbed the great rejuvenation of the Chinese nation. (Greeen, 2017) The Chinese Communist Party's legitimacy is linked to its pledge to achieve the reunification of Taiwan with the motherland. A commonly held view on the mainland is that no Chinese leader could remain in power if he allowed Taiwan to separate from the PRC and be recognised by the international community as an independent sovereign state (Greeen, 2017)

China under the communist party has seen tremendous growth. It is the world's secondlargest economy by both nominal GDP and purchasing power parity (PPP) and a permanent member of the United Nations Security Council. It is the world's largest exporter, the secondlargest importer of goods and the fastest-growing major economy. China is a recognised nuclear weapons state and has the world's largest standing army with the second-largest defence budget (Diffen, 2012). Taiwan is also an economic powerhouse with an industrialised, developed economy and high standard of living. The ROC is a member of the WTO and APEC, one of the Four Asian Tigers, and the 26th-largest economy in the world. 
It is a major manufacturer of electronic goods such as semiconductor chips, phones and computers. The ROC is ranked high in terms of freedom of the press, health care, public education and economic freedom unlike its neighbours (Diffen, 2012)

Simply put, the "One-China policy" is a policy asserting that there is only one sovereign state under the name China, as opposed to the idea that there are two states, the People's Republic of China (PRC) and the Republic of China (ROC). In 1979, the United States moved to recognise the People's Republic of China (PRC) and de-recognize the Republic of China (ROC) and affirmed the PRC as "the sole legal Government of China" (Greeen, 2017).

It is important to note that the one-China policy is different from the "One China principle". The one-China policy is an agreement with the People's Republic of China by the United States and its allies including the United Nations that the communist party controlled the geographical spaces known today as China. The one-China principle on the other hand is the ideology of the Peoples Republic of China which insists that both Taiwan and mainland China are inalienable parts of a single "China." Article 2 of the Anti-Secession law states that, "There is only one China in the world." Both the mainland and Taiwan belong to one China. China's sovereignty and territorial integrity brook no division. Safeguarding China's sovereignty and territorial integrity is the common obligation of all Chinese people, the Taiwan compatriots included. Taiwan is part of China. The state shall never allow the "Taiwan independence" secessionist forces to make Taiwan secede from China under any name or by any means (Law, 2005). Article 5 exacerbated this point further. It states that "Upholding the principle of one China is the basis of peaceful reunification of the country. To reunify the country through peaceful means best serves the fundamental interests of the compatriots on both sides of the Taiwan Straits. The state shall do its utmost with maximum sincerity to achieve a peaceful reunification. After the country is reunified peacefully, Taiwan may practise systems different from those on the mainland and enjoy a high degree of autonomy (Law, 2005). The PRC and the ROC agreed to a consensus in 1992 where both governments "agree" that there is only one sovereign state encompassing both mainland China and Taiwan, but disagree about which of the two governments is the legitimate government of this state. The one-China principle however is rejected by Taiwanese as they attempt to preserve their identity.

December 2016 witnessed a diplomatic firestorm when then US President-elect Donald Trump had a 10-minute conversation with Taiwan's President Tsai Ing-wen. Even before Trump, the United States and Taiwan has enjoyed a robust unofficial relationship. This, however, does not validate Taiwan independence claims as the United States does not support Taiwan independence. In 1979 President Jimmy Carter established formal diplomatic ties with Beijing and switched diplomatic recognition from Taipei to Beijing. In the Joint Communiqué, the United States recognised the Government of the People's Republic of China as the sole legal government of China, acknowledging the Chinese position that there is but one China and Taiwan is part of China (State, 2018). To further buttress this point, the United States released a U.S.-China Communiqué in August 1982 stating that it had no intention of pursuing a policy of "two Chinas" or "one China, one Taiwan."The Joint Communiqué also states that the people of the United States will maintain cultural, commercial, and other unofficial relations with the people of Taiwan. The American Institute in Taiwan (AIT) is responsible for implementing U.S. policy toward Taiwan (State, 2018). In the same year, 1979, the United States passed the Taiwan Relations Act, which guarantees support for the island. Although the PRC demanding the US recognize its sovereignty over Taiwan, Washington instead acknowledged the Chinese position that Taiwan was part of China and mostly for geopolitical reasons; both 
the United States and the PRC were willing to go forward with diplomatic recognition despite their differences on this matter. To this day, the U.S. "one China" position stands: the United States recognises the PRC as the sole legal government of China but only acknowledges the Chinese position that Taiwan is part of China. Thus, the United States maintains formal relations with the PRC and has unofficial relations with Taiwan (Krasner, 2001).

The question is, "why is Taiwan important to the United States of America"? The reason is not farfetched. Taiwan ended martial law in 1987 and held its first direct democratic presidential election in 1996 and has become a fully functioning democracy, respects human rights and the rule of law, and has an open economy that, in 2015, made it the ninth-largest U.S. trading partner, with bilateral trade between the United States and Taiwan reaching \$66.6 billion. (Greeen, 2017). In reality, the U.S has supported the Taiwanese economically even before 1979. Taiwan enjoys Export-Import Bank financing, Overseas Private Investment Corporation guarantees, normal trade relations status, and ready access to U.S. markets (State, 2018). AIT has been engaged in a series of trade discussions that have focused on the protection of intellectual property rights and market access for U.S. goods and services. The United States has a trade and investment framework agreement with Taiwan under the auspices of AIT and the Taipei Economic and Cultural Representative Office (TECRO) in the United States. As of 2013, companies from Taiwan employed more than 12,000 workers in the United States with total worker compensation of almost a billion dollars (State, 2018).

People-to-people ties between the United States and Taiwan continue to grow. There are now 148 sister cities between the United States and Taiwan, connecting our two societies on a local level and Travel for business and pleasure from Taiwan to the United States has increased 50 per cent since Taiwan became a member of the U.S. Visa Waiver Program in November 2012 (State, 2018).

The United States supports Taiwan's membership in international organisations that do not require statehood as a condition of membership and encourages Taiwan's meaningful participation in international organisations where its membership is not possible. Taiwan and the United States belong to a number of the same international organisations, including the World Trade Organisation, the Asia-Pacific Economic Cooperation forum, and the Asian Development Bank. In June 2015, AIT and TECRO established the Global Cooperation and Training Framework, a platform for expanding U.S.-Taiwan cooperation on global and regional issues such as public health, economic development, energy, women's rights, and disaster relief (State, 2018).

The reality on ground is that Beijing is wary of the relationship that exists between the U.S and Taiwan. What scares Beijing the most is the sale of weapons and military hardware sold by the U.S to Taiwan. BBC recently reported that the US has approved arms sales to Taiwan worth around \$1.8bn. The Pentagon said the deal comprised three weapons systems, including rocket launchers, sensors and artillery. Taiwan's Defence Ministry said the weapons would help it "build credible combat capabilities and strengthen the development of asymmetric warfare" (BBC, 2020). The US has said it insists on the peaceful resolution of differences between the two sides and encourages both sides to pursue "constructive dialogue." China's Foreign Ministry says the arms deal would likely have a major impact on its relationship with the US and that it would respond as necessary. (BBC, 2020) Beijing strongly criticised The selling of weapons to Taiwan and warns the US "not to send any wrong signals to 'Taiwan independence' 
China has also stepped up military drills that it presents domestically as rehearsals for a future invasion of Taiwan, though experts say a conflict is not imminent (BBC, 2020).

\section{Theoretical Framework}

This paper employs the Neo-realist or structural realism, which is a theory of international relations that argues that power, interest and security are the most important factors in international relations. Neorealism is one of the two most influential contemporary approaches to international relations; the two perspectives have dominated international relations theory for the last three decades. Neorealism focuses discussion on the anarchical nature of the global system as against the human nature in classical realism. The absence of international police creates anarchy within the system, thereby making powerful states invade weaker ones and allows others to acquire power for self-defence. Taiwan tries to balance power with the United States against China which bows to return Taiwan to the mainland, but Taiwan continues to enjoy American support. China would therefore have no option other than acquiring more power to counter Taiwan-American power or to have Russia as a balancer in case there is going to be a confrontation between the major parties involved.

\section{FINDINGS AND DISCUSSION}

The positioning of China and the United States has drastically changed since the 1979 resolution. China has covered a lot of ground and is second only to the United States in Economy and Military Budget. According to Sheriff (2020), the United States of America has developed a phobia towards China because of the speed of development in China (Ibrahim, 2020). Sheriff (2020) further argues that this fear emanates from the obvious decline of the United States and it has further pushed the U.S to build alliances like the pact with Taiwan in an attempt to destabilize the growing strength of the Communist Party and the People's Republic of China.

The Implication of U.S support to Taiwan has seen an increased assertiveness of China's hold in the region. Beijing has continued to reach up to its pressure campaign against Taipei, which ranges from disinformation campaigns to poaching some of Taiwan's few remaining diplomatic allies. Over the last several months, Chinese military aircraft have made an unprecedented number of incursions across the median line of the Taiwan Strait (Blanchard, 2020). Taiwan complains that China is poaching the dwindling number of countries that maintain formal ties with Taipei and has prevented it from participating in bodies like the World Health Organization. The United States continues to strengthen ties with Taiwan which have given rise to The Taiwan Allies International Protection and Enhancement Initiative (TAIPEI) Act, signed by Trump into law on Thursday with strong bipartisan support, requires the U.S. State Department to report to Congress on steps taken to strengthen Taiwan's diplomatic relations (Blanchard, 2020). 
African Journal of Law, Political Research and Administration

ISSN: 2689-5102

Volume 4, Issue 2, 2021 (pp. 40-52)

www.abjournals.org

Table 1.1: U.S. trade in goods with Taiwan, 2016 in millions of U.S. dollars

\begin{tabular}{|l|r|r|r|}
\hline \multicolumn{1}{|c|}{ Month } & \multicolumn{1}{c|}{ Exports } & \multicolumn{1}{c|}{ Imports } & \multicolumn{1}{c|}{ Balance } \\
\hline January 2016 & $2,148.7$ & $3,252.6$ & $-1,104.0$ \\
\hline February 2016 & $1,844.4$ & $2,964.3$ & $-1,119.9$ \\
\hline March 2016 & $2,002.8$ & $2,968.8$ & -966.1 \\
\hline April 2016 & $1,962.3$ & $3,041.7$ & $-1,079.4$ \\
\hline May 2016 & $2,186.6$ & $3,337.7$ & $-1,151.1$ \\
\hline June 2016 & $2,245.5$ & $3,380.4$ & $-1,134.9$ \\
\hline July 2016 & $2,065.8$ & $3,228.0$ & $-1,162.2$ \\
\hline August 2016 & $1,948.3$ & $3,644.1$ & $-1,695.8$ \\
\hline September 2016 & $2,605.3$ & $3,313.6$ & -708.4 \\
\hline October 2016 & $2,338.0$ & $3,345.8$ & $-1,007.8$ \\
\hline November 2016 & $2,031.3$ & $3,364.5$ & $-1,333.2$ \\
\hline December 2016 & $2,655.0$ & $3,357.2$ & -702.2 \\
\hline TOTAL 2016 & $\mathbf{2 6 , 0 3 3 . 9}$ & $\mathbf{3 9 , 1 9 8 . 8}$ & $\mathbf{- 1 3 , 1 6 4 . 9}$ \\
\hline
\end{tabular}

Source: United States Census, 2016

It can be seen from the above table that, the United States has been importing more than it exports to Taiwan between January and December 2016, with a total export worth of 26, 033.9 Dollars of goods to Taiwan, and 39, 198, 8 Dollars worth of import from Taiwan.

Table I.2:U.S. trade in goods with Taiwan 2018 in millions of U.S. dollars

\begin{tabular}{|l|r|r|r|}
\hline \multicolumn{1}{|c|}{ Month } & \multicolumn{1}{c|}{ Exports } & \multicolumn{1}{c|}{ Imports } & \multicolumn{1}{c|}{ Balance } \\
\hline January 2018 & $2,120.4$ & $3,767.6$ & $-1,647.3$ \\
\hline February 2018 & $1,833.8$ & $3,207.4$ & $-1,373.7$ \\
\hline March 2018 & $2,385.6$ & $3,468.2$ & $-1,082.6$ \\
\hline April 2018 & $2,419.4$ & $3,520.9$ & $-1,101.5$ \\
\hline May 2018 & $2,416.3$ & $3,789.2$ & $-1,372.9$ \\
\hline June 2018 & $2,591.7$ & $3,874.5$ & $-1,282.8$ \\
\hline July 2018 & $2,827.0$ & $3,939.8$ & $-1,112.8$ \\
\hline August 2018 & $2,811.2$ & $3,894.0$ & $-1,082.8$ \\
\hline
\end{tabular}


African Journal of Law, Political Research and Administration

ISSN: 2689-5102

Volume 4, Issue 2, 2021 (pp. 40-52)

www.abjournals.org

\begin{tabular}{|l|r|r|r|}
\hline September 2018 & $2,787.0$ & $3,685.4$ & -898.4 \\
\hline October 2018 & $2,863.3$ & $4,246.8$ & $-1,383.5$ \\
\hline November 2018 & $2,479.0$ & $4,161.0$ & $-1,682.1$ \\
\hline December 2018 & $2,945.0$ & $4,177.1$ & $-1,232.2$ \\
\hline TOTAL 2018 & $\mathbf{3 0 , 4 7 9 . 7}$ & $\mathbf{4 5 , 7 3 2 . 1}$ & $\mathbf{- 1 5 , 2 5 2 . 4}$ \\
\hline
\end{tabular}

Source: United States Census, 2018

It can be seen from the above table that trade between the United States and Taiwan favours Taiwan, as it sells more than it buys from the United States. It is clear that within the period of January to December 2018, Taiwan has sold to the United States volume of goods worth 45,732.1 Dollars and bought goods worth 30,479.7 Dollars from the United States.

Table 1.3: U.S. trade in goods with Taiwan 2020 in millions of U.S. dollars

\begin{tabular}{|l|r|r|r|}
\hline \multicolumn{1}{|c|}{ Month } & \multicolumn{1}{c|}{ Exports } & \multicolumn{1}{c|}{ Imports } & \multicolumn{1}{c|}{ Balance } \\
\hline January 2020 & $2,720.2$ & $4,840.0$ & $-2,119.8$ \\
\hline February 2020 & $2,736.4$ & $3,984.5$ & $-1,248.1$ \\
\hline March 2020 & $2,862.4$ & $4,549.2$ & $-1,686.8$ \\
\hline April 2020 & $2,388.9$ & $4,640.9$ & $-2,252.0$ \\
\hline May 2020 & $2,187.7$ & $4,852.4$ & $-2,664.7$ \\
\hline June 2020 & $2,255.3$ & $4,804.4$ & $-2,549.1$ \\
\hline July 2020 & $2,290.0$ & $5,310.9$ & $-3,020.9$ \\
\hline August 2020 & $2,476.6$ & $5,126.0$ & $-2,649.3$ \\
\hline September 2020 & $2,723.6$ & $5,552.4$ & $-2,828.8$ \\
\hline October 2020 & $2,568.9$ & $5,614.3$ & $-3,045.4$ \\
\hline November 2020 & $2,589.1$ & $5,448.6$ & $-2,859.5$ \\
\hline December 2020 & $2,697.1$ & $5,704.0$ & $-3,007.0$ \\
\hline TOTAL 2020 & $\mathbf{3 0 , 4 9 6 . 3}$ & $\mathbf{6 0 , 4 2 7 . 7}$ & $\mathbf{2 9 , 9 3 1 . 4}$ \\
\hline
\end{tabular}

Source: United States Census, 2020

It is evident from the above table that trade between the two partners in goods is in favour of Taiwan, as it exported a volume of goods worth 60, 427.7 Million Dollars and imported goods worth 30,496.3 Million Dollars from the United States between January and December 2020. 
Table 1.4: U.S. trade in goods with China 2016 in millions of U.S. dollars

\begin{tabular}{|l|r|r|r|}
\hline \multicolumn{1}{|c|}{ Month } & \multicolumn{1}{c|}{ Exports } & \multicolumn{1}{c|}{ Imports } & \multicolumn{1}{c|}{ Balance } \\
\hline January 2016 & $8,208.9$ & $37,126.4$ & $-28,917.5$ \\
\hline February 2016 & $8,080.5$ & $36,066.9$ & $-27,986.4$ \\
\hline March 2016 & $8,925.6$ & $29,812.3$ & $-24,240.5$ \\
\hline April 2016 & $8,679.7$ & $32,920.2$ & $-28,971.8$ \\
\hline May 2016 & $8,542.0$ & $37,513.7$ & $-29,693.6$ \\
\hline June 2016 & $8,845.6$ & $38,539.2$ & $-30,309.2$ \\
\hline July 2016 & $9,129.7$ & $39,438.9$ & $-33,848.9$ \\
\hline August 2016 & $9,372.9$ & $43,221.8$ & $-32,499.8$ \\
\hline September 2016 & $9,521.2$ & $42,020.9$ & $-31,198.1$ \\
\hline October 2016 & $12,600.0$ & $43,798.1$ & $-30,558.5$ \\
\hline November 2016 & $12,044.1$ & $42,602.6$ & $-27,714.1$ \\
\hline December 2016 & $11,644.8$ & $39,358.9$ & $\mathbf{- 3 4 6 , 8 2 5 . 2}$ \\
\hline TOTAL 2016 & $\mathbf{1 1 5 , 5 9 4 . 8}$ & $\mathbf{4 6 2 , 4 2 0 . 0}$ & \\
\hline
\end{tabular}

Source: United States Census, 2016

It is apparent in the above table that whatever trade relation that is between the United States and Taiwan in 2016, the United States imported from China more than it did from Taiwan. It can also be seen from the table that China imported less than it exported from and to the United States, which shows that the trade absolutely favours China. The U.S export to China was 115,594.8, while import was 462, 420.0 in the year 2016 .

Table 1.5: U.S. trade in goods with China 2018 in millions of U.S. dollars

\begin{tabular}{|l|r|r|r|}
\hline \multicolumn{1}{|c|}{ Month } & \multicolumn{1}{c|}{ Exports } & \multicolumn{1}{c|}{ Imports } & \multicolumn{1}{c|}{ Balance } \\
\hline January 2018 & $9,910.2$ & $45,749.9$ & $-35,839.7$ \\
\hline February 2018 & $9,741.8$ & $39,003.6$ & $-29,261.9$ \\
\hline March 2018 & $12,653.2$ & $38,295.1$ & $-25,641.9$ \\
\hline April 2018 & $10,510.5$ & $38,269.4$ & $-27,758.9$ \\
\hline May 2018 & $10,396.6$ & $43,938.7$ & $-33,542.0$ \\
\hline June 2018 & $10,858.3$ & $44,571.2$ & $-33,712.9$ \\
\hline July 2018 & $10,156.5$ & $47,087.6$ & $-36,931.1$ \\
\hline
\end{tabular}


African Journal of Law, Political Research and Administration

ISSN: 2689-5102

Volume 4, Issue 2, 2021 (pp. 40-52)

www.abjournals.org

\begin{tabular}{|l|r|r|r|}
\hline August 2018 & $9,280.9$ & $47,817.5$ & $-38,536.6$ \\
\hline September 2018 & $9,732.4$ & $49,988.1$ & $-40,255.7$ \\
\hline October 2018 & $9,187.5$ & $52,170.1$ & $-42,982.6$ \\
\hline November 2018 & $8,650.9$ & $46,445.7$ & $-37,794.8$ \\
\hline December 2018 & $9,210.5$ & $45,906.3$ & $-36,695.9$ \\
\hline TOTAL 2018 & $\mathbf{1 2 0 , 2 8 9 . 3}$ & $\mathbf{5 3 9 , 2 4 3 . 1}$ & $\mathbf{- 4 1 8 , 9 5 3 . 9}$ \\
\hline
\end{tabular}

Source: United States Census, 2018

Same as in 2016, the 2018 trade year between the United States and China from January to December shows that the trade relations favour China as it exports more than it imports to the United States, with a total volume of goods exported to the U.S worth 539,243.1 and total imported just 120,289.3.

Table 1.6: U.S. trade in goods with China 2020 in millions of U.S. dollars

\begin{tabular}{|l|r|r|r|}
\hline \multicolumn{1}{|c|}{ Month } & \multicolumn{1}{c|}{ Exports } & \multicolumn{1}{c|}{ Imports } & \multicolumn{1}{c|}{ Balance } \\
\hline January 2020 & $7,215.3$ & $33,280.6$ & $-26,065.3$ \\
\hline February 2020 & $6,815.0$ & $22,813.1$ & $-15,998.1$ \\
\hline March 2020 & $7,971.9$ & $19,805.4$ & $-11,833.5$ \\
\hline April 2020 & $8,604.7$ & $31,070.8$ & $-22,466.1$ \\
\hline May 2020 & $9,641.7$ & $36,598.2$ & $-26,956.5$ \\
\hline June 2020 & $9,242.2$ & $37,639.5$ & $-28,397.2$ \\
\hline July 2020 & $9,037.0$ & $40,657.3$ & $-31,620.2$ \\
\hline August 2020 & $11,036.1$ & $40,816.4$ & $-29,780.4$ \\
\hline September 2020 & $11,536.8$ & $41,208.3$ & $-29,671.6$ \\
\hline October 2020 & $14,723.0$ & $44,828.0$ & $-30,105.0$ \\
\hline November 2020 & $14,179.3$ & $44,855.5$ & $-30,676.2$ \\
\hline December 2020 & $14,645.5$ & $41,875.9$ & $-27,230.4$ \\
\hline TOTAL 2020 & $\mathbf{1 2 4 , 6 4 8 . 5}$ & $\mathbf{4 3 5 , 4 4 9 . 0}$ & $\mathbf{- 3 1 0 , 8 0 0 . 5}$ \\
\hline
\end{tabular}

Source: United States Census, 2020 
Despite the COVID-19 pandemic in the year 2020, trade relations between the two largest economies of the world have been significant. The shows that there is a drop in the volume of export and import, but the digits have been relatively strong. The United States exported 124,648.5 worth of goods to China between January and December 2020 and imported 435, 449.0 worth of goods from China. This shows that trade relations between the two in 2020 still favoured China.

All the tables above show that the United States buy more from both China and Taiwan, and sell less to both. It is also evident that the U.S. buys more from China than from Taiwan and in economic terms, it means the United States should have more to share with China than with Taiwan. In international relations, there is no permanent friend nor permanent enemy, but permanent interest, hence the American invariable support to Taiwan due to American interest and the move to contain China.

\section{CONCLUSION}

The relationship enjoyed by the U.S and Taiwan is invariably leading to one conclusion, a faceoff between the world's most powerful countries, China and the United States. China has stepped up its military drills around Taiwan in recent weeks. In a press briefing, the Chinese foreign ministry spokesman Geng Shuang said the U.S. act of support to Taiwan contravenes international law, was a "crude" interference in China's internal affairs and obstructed other sovereign states from developing normal relations with China."We urge the United States to correct its mistakes, not implement the law or obstruct the development of relations between other countries and China, otherwise, it will inevitably encounter a resolute strike back by China," Geng said, without giving details (Gen, 2020).

Since Donald Trump came to power, and especially since the end of 2017, China-US relations have witnessed historic changes, including the largest tariff war in the history of international economic relations as well as a subtle technological war against China by the US. The only experiential outcome possible is a financial war between the two giants in 2020. This is not unrelated to the U.S support for Taiwan. The author outlines five evolution points to the Cold War between the U.S. and the Soviet Union; strategic distrust, ideological attacks, closed exclusive economies, security struggle, and the influence of third parties. Wei Li argues that that the hostility between the U.S and China can be seen when the "US strategic circles held a 3 -year policy debate on China beginning in 2015. The US then introduced a number of hardline foreign policies towards China, marked by the introduction of the National Security Strategy of the US at the end of 2017. Accordingly, China responded strongly, and On May 20, 2020, the US issued the United States Strategic Approach to the People's Republic of China, officially announcing the end of its engagement strategy and designating the US strategy to China" (Li, 2020).

It is true that at the moment, China is still not capable of engaging the U.S. in a physical war, but building its economy which would give it strong power above the United States any time soon and China cannot forfeit the strait of Taiwan despite American support to the island. The deteriorating relationship between the U.S and China relationship has seen trade wars to accusations on the origins of the coronavirus to political buffering, to the sovereign of Taiwan and Hongkong; it just seems to be a manifestation of the Sino-American Cold War. The way 
things appear, the relationship between the U.S and China will further deteriorate largely because democracy and liberal order are being challenged by the political posture of China. This is further enhanced by the steady growth of China's economic capabilities. The recent confrontation in Hong Kong and Taiwan only makes it worse. It is hoped that U.S. and China should find mutually beneficial avenues to prevent a repeat of the Cold War.

\section{RECOMMENDATIONS}

There are obstructions in any form of relations that create rivalry and sometimes even lead to violent conflicts around the world. The U.S-China relations can be improved with the following recommendations:

There is the need to maintain the non-interference principle by the two parties, the United States should know that Taiwan is China and therefore not meddle in the affairs of China and viceversa.

The United States though pursuing geopolitical strategy and concentrating in south-east Asia should always remember that there is a world rising power in that region which is China. Competition and struggle for dominance may not yield a fruitful result for the region and the entire world.

The two should avoid forming unhealthy alliances against each other as it happened prior to the First World War among European states. The resolve by the G-7 the counter China's Belt and Road Initiative is a plot to provoke China by member-states of this economic forum. They should form their own initiative which can compete economically for the benefits of humanity not against the Chinese OBOR.

\section{REFERENCES}

Affairs, T. (2008, August 2). The One-China Principle and the Taiwan Issue". Taiwan: Taiwan Affairs Office.

BBC. (2020, October 22). US approves \$1.8bn weapons sale to Taiwan. Retrieved from BBC News: https://www.bbc.com/news/world-asia-

54641076\#: :text=US\%20approves\%20\%241.8bn\%20weapons\%20sale\%20to\%20Tai wan.\%20The, artillery.\%20Taiwan $\% 2 \mathrm{C} \% 20$ which $\% 20$ considers $\% 20$ itself $\% 20 \mathrm{a} \% 20 \mathrm{cou}$ ntry $\% 2 \mathrm{C} \% 20$

Blanchard, B. (2020, March 27). U.S. increases support for Taiwan, China threatens to strike back. Retrieved from Reuters: https://www.reuters.com/article/us-taiwan-usaidUSKBN21E0B7

Diffen. (2012). People's Republic Of China vs. Republic Of China. Retrieved from People's Republic Of China vs. Republic Of China:

https://www.diffen.com/difference/People\%27s_Republic_Of_China_vs_Republic_Of_ China\#: :text=The\%20People\%27s\%20Republic\%20of\%20China\%20is\%20commonly $\% 20$ known,was $\% 20$ governed $\% 20$ by $\% 20$ the $\% 20$ Republic $\% 20$ of $\% 20$ China $\% 20 \% 28$ RO $\mathrm{C} \% 29$. 
Greeen, M. J. (2017, January 13). What Is the U.S. "One China” policy, and Why Does it Matter? Retrieved from Center for Strategic \& International Studies: https://www.csis.org/analysis/what-us-one-china-policy-and-why-does-it-matter

Ibrahim, s. G. (2020). CHINA-PHOBIA AND THE DECLINE OF AMERICAN EMPIRE: MYTH OR REALITY. Retrieved from Academia.edu: https://www.academia.edu/45107143/CHINA_PHOBIA_AND_THE_DECLINE_OF_ AMERICAN_EMPIRE_MYTH_OR_REALITY

Krasner, S. (2001). Problematic Sovereignty: Contested Rules and Political Possibilities. . Columbia: Columbia University Press.

Law, A.-S. (2005). "Anti-Secession Law". China: The People's Daily.

Li, W. (2020, June 20). Why do we need to revisit the Cold War? Retrieved from China International Strategy Review: https://link.springer.com/content/pdf/10.1007\%2Fs42533-020-00047-7.pdf

Slate. (2000, May 24). What Is the One-China Policy? Retrieved from Slate: https://slate.com/news-and-politics/2000/05/what-is-the-one-china-policy.html

State, U. D. (2018, August 31). U.S Relations with Taiwan. Retrieved from U.S Relations with Taiwan: https://www.state.gov/u-s-relations-with-taiwan/ 